\title{
Retraction: Dominant B cell receptor clones in peripheral blood predict onset of arthritis in individuals at risk for rheumatoid arthritis
}

Paul Peter Tak, Marieke Doorenspleet, Marjolein de Hair, Paul Klarenbeek, Marian van Beers-Tas, Antoine van Kampen, Dirk Jan van Schaardenburg, Danielle Gerlag, Frank Baas, Niek de Vries.

This article has been retracted.

The editors of Ann Rheum Dis have been notified by Professor Paul Peter Tak and Professor Niek de Vries of the Amsterdam University Medical Center, Amsterdam, The Netherlands that they and the other authors of the above article wish to retract the paper.

The authors state:

During follow-up studies to advance our insights into the role of B cell clones during the earliest stage of rheumatoid arthritis (RA), we observed that we could not detect some of the clones that we previously described in subjects at risk of developing RA. After subsequent review of the original data published in Ann Rheum Dis 2017;76(11):1924-1930, we detected errors in assignment of clinical data to sequencing data. As a result, we cannot support the conclusions of the article anymore and we wish to retract the publication. Further investigation into the source of the error is ongoing. We communicate our sincere apologies.

Related publications affecting this retraction:

- Tak PP, M.E. Doorenspleet, M.J.H. de Hair, P.L. et al. Dominant B-cell receptor clones in peripheral blood predict onset of arthritis in individuals at risk for rheumatoid arthritis [Abstract 08.21]. European Workshop for Rheumatology Research March fourth 2017, Athens, Greece. Ann Rheum Dis 2017; 76 (Suppl 1); A83. https://ard.bmj.com/content/ 76/Suppl_1/A83.2

- Tak PP, Doorenspleet ME, de Hair M, et al. Dominant B-Cell Receptor Clones in Peripheral Blood Predict Onset of Arthritis in Individuals at Risk for Rheumatoid Arthritis [abstract OP0173]. EULAR 2017, Madrid, Spain. Ann Rheum Dis 2017; 76 (Suppl 2):124.

- Musters A, van Beers-Tas MH, Doorenspleet ME, et al. Dominant B cell receptor clones in peripheral blood predict onset of arthritis in individuals at risk for Rheumatoid Arthritis a validation cohort. Abstract OP0204. Ann Rheum Dis, volume 77 Suppl 2, 2018, A151. Further information may be available from the authors.

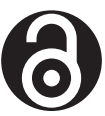

\section{OPEN ACCESS}

\begin{abstract}
Open access This is an open access article distributed in accordance with the Creative Commons Attribution Non Commercial (CC BY-NC 4.0) license, which permits others to distribute, remix, adapt, build upon this work noncommercially, and license their derivative works on different terms, provided the original work is properly cited, appropriate credit is given, any changes made indicated, and the use is non-commercial. See: http://creativecommons.org/licenses/by-nc/ 4.0\%.

(c) Author(s) (or their employer(s)) 2021. Re-use permitted under CC BY-NC. No commercial re-use. See rights and permissions. Published by BMJ.
\end{abstract}

Ann Rheum Dis 2021;80:e139. doi:10.1136/annrheumdis-2017-211351ret

Check for updates 